VELASCO-LÓPEZ, F; MARTÍNEZ-GUTIÉRREZ, GA; MORALES, I; VASQUEZ-LÓPEZ, A; ESCAMIROSA-TINOCO, C. 2020. Photosynthetically active radiation in strawberry produced in stair-like containers. Horticultura Brasileira 38: 5-11. DOI - http://dx.doi.org/10.1590/S0102-053620200101

\title{
Photosynthetically active radiation in strawberry produced in stair-like containers
}

\author{
Federico Velasco-López ${ }^{1} \mathbb{D}$; Gabino A Martínez-Gutiérrez ${ }^{1} \mathbb{D}$; Isidro Morales ${ }^{1} \mathbb{D}$; Alfonso Vasquez-López ${ }^{1} \mathbb{D}$; \\ Cirenio Escamirosa-Tinoco ${ }^{1} \mathbb{D}$
}

${ }^{1}$ Instituto Politécnico Nacional, Centro Interdisciplinario de Investigación para el Desarrollo Integral Regional (CIIDIR) Unidad Oaxaca, Santa Cruz Xoxocotlán Oaxaca, México (*author for correspondence: gamartinez@ipn.mx)

\begin{abstract}
In intensive hydroponic systems, such vertical and pyramidal systems, photosynthetically active radiation (PAR) and integrated (IPAR) may be intercepted by the containers and the leaf area of the plants grown in the upper strata, decreasing fruit yields and quality. The objective of this study was to evaluate the behavior of PAR and IPAR at different planting heights and the effect of geographic orientation and fruit yield and quality of strawberry produced in stair-like containers. The factors were four heights of the container $(0.20,0.50,0.80$ and $1.10 \mathrm{~m})$ and two orientations (east and west). At each height and orientation of the container, PAR and IPAR, yield and fruit total soluble solids were measured. PAR and IPAR were statistically different at all heights evaluated and were highest in the highest containers. The east and west orientation of the containers was significantly different in the morning and in the afternoon for PAR and IPAR, while daily average values were equal. Yield on average was $47 \%$ higher in plants cultivated in containers at heights of $0.50,0.80$ and $1.10 \mathrm{~m}$, relative to those in $0.20 \mathrm{~m}$ high containers. Fruits grown in the highest containers had higher values of total soluble solids.
\end{abstract}

Keywords: Fragaria ananassa, fruit quality, soilless culture, intensive production.

\section{RESUMO}

Radiacão fotossinteticamente ativa em morango produzido em recipientes de cultivo escalariformes

Em sistemas de cultivo hidropônico intensivos, como os verticais e piramidais, a radiação fotossinteticamente ativa (PAR) e integrada (RFAI) podem diminuir ao longo dos recipientes de cultivo e do dossel das plantas localizados nos estratos mais inferiores, diminuindo a produtividade e a qualidade dos frutos. No presente estudo foi avaliado o efeito da altura e da orientação geográfica dos recipientes de cultivo hidropônico, em um sistema escalariforme, na RFA, na RFAI, e na produção e qualidade de frutos de morango. Em cada altura e orientação, as variáveis RFA, RFAI, produtividade e qualidade dos frutos foram registrados. A orientação leste-oeste dos recipientes de cultivo foi diferente na parte da manhã e da tarde para a RFA e RFAI recebidas pelas plantas de morango em todas as alturas dos recipientes, enquanto que os valores médios diários foram iguais. A produtividade foi, em média, 47\% mais elevada nas plantas cultivadas a $0.50,0.80$ e $1.10 \mathrm{~m}$ de altura do recipiente de cultivo, em comparação com as plantas cultivadas a $0.20 \mathrm{~m}$ de altura. A qualidade de frutos também foi melhor nos três recipientes de cultivo mais elevados.

Palavras-chave: Fragaria ananassa, qualidade da fruta, cultivo sem solo, produção intensiva.

\section{Received on May 30, 2019; accepted on December 13, 2019}

$\mathrm{O}$ ne of the functions of plant leaves is interception of the solar radiation necessary for photosynthesis and production of carbohydrates. Of the radiation the earth receives, only the ones between 0.400 and $0.700 \mu \mathrm{m}$ are used; this is the photosynthetically active radiation (PAR) (Oyarzún et al., 2011), which affects crop growth and development by its effects on photomorphogenesis and mutamorphogenesis (Johkan et $a l .$, 2012). Each plant species has an optimal range of PAR that maximizes photosynthesis and growth. When there is not enough light, growth is slow and fruit quality decreases, and when there is excessive light, photosynthesis does not increase, nor does plant grow. In the leaf, photosynthetic efficiency is higher with low levels of radiation (Norman \& Arkebauer, 1991) because the leaves become saturated with radiation when they are exposed to direct sunlight.

Worldwide, Mexico is the third producer of strawberry. In 2018, the cultivated area was 13,563 ha (SIAP, 2018). The states with the largest cultivated area are Michoacán, Baja California and Guanajuato; $69 \%$ of this area is field cultivated under full sunlight with $4.62 \mathrm{~kg} \mathrm{~m}^{-2}$ average yield (SIAP, 2018), considered low. On the rest of the area some sort of technology is used, such as mulching and fertigation (PRNF, 2012). Of this production, $70 \%$ is exported to Canada, the United States, Brazil, Saudi Arabia and the United Kingdom (SAGARPA, 2016). During the last decade, demand has increased so that it has been necessary to incorporate new technologies to increase yields, such as plastic covering in protective structures, drip irrigation and hydroponics. Intensive hydroponic 
systems have several great advantages over the traditional system in soil and full sunlight, for example, efficient use of water and fertilizers, and optimization of crop space and management. Moreover, in small areas, vertical or horizontal hydroponic systems permit increased planting density and, consequently, yield, while guaranteeing fruit safety.

To optimize greenhouse area in protected and intensive agriculture, strawberry cultivation in suspended containers or in vertical systems has been studied (Fernandes-Junior et al., 2002). Using vertical containers increased yields up to $100 \%$, relative to use of horizontal containers (FernandesJunior et al., 2002). In tall horticultural species, such as tomato (L. esculentum), pyramid and stair-like systems have also been used (Sánchez-del-Castillo et al., 2009) with which high yields have been obtained. In these systems, plants grown in the upper canopies achieved higher yields than those grown in the lower canopies (Sánchez-del-Castillo et al., 2014) because they received more PAR. In strawberries grown in vertical systems, Calvete et al. (2007) found that yield decreased from the upper to the lower part and attributed the difference to differences in PAR. The decrease in PAR was due to the shade caused by leaves of the plants in the upper part. In vertical systems the upper canopies use a part of the incident radiation; the rest passes unintercepted through the holes in the canopy and reaches the ground (López-Lozano et al., 2007) or through spaces with no leaves or stems. These spaces can be up to $40 \%$ (España-Boquera et al., 2015). This space is useful in stair-like containers with strawberries since it allows direct solar radiation to reach the lower canopies, which also make use of diffused radiation that can reach up to 30\% (Higashide, 2008).

Plant species require different levels of IPAR, ranging from $<5,5-10,10-20$, 20-30 and $>30 \mathrm{~mol} \mathrm{~m}^{-2} \mathrm{~d}^{-1}$. Strawberry plants have requirements between 10 and $20 \mathrm{~mol} \mathrm{~m}^{-2} \mathrm{~d}^{-1}$ (Torres et al., 2011). IPAR also determines metabolite concentration in the plants (Gent, 2014): the more the radiation, the higher the content of sugars and dry matter (López
\& Runkle, 2008). The objective of this study was to evaluate the behavior of PAR, IPAR and fertigation at different heights and geographic orientation of strawberries in stair-like containers and their effect on fruit yield and quality.

\section{MATERIAL AND METHODS}

\section{Study site}

This study was conducted in the experimental farm of CIIDIR Oaxaca Unit of the Instituto Politécnico Nacional, located in Santa Cruz Xoxocotlán, Oaxaca, Mexico $\left(17^{\circ} 01^{\prime} 31^{\prime \prime} \mathrm{N}\right.$, $96^{\circ} 43^{\prime} 12^{\prime \prime} \mathrm{W}$, altitude $1526 \mathrm{~m}$ ) from January to June 2016.

\section{Stair-like hydroponic modules}

In the $20 \times 8 \times 5 \mathrm{~m}$ (length $\times$ width $\times$ height) tunnel-type greenhouse covered with $200 \mu \mathrm{m}$ white polyethylene, three stair-like modules were constructed to cultivate strawberries in hydroponics. For each module, eight white PVC tubes, $15.24 \mathrm{~cm}$ diameter by $6.0 \mathrm{~m}$ long, were used. The final dimensions of each model were $1.4 \times 3.0 \times 1.10 \mathrm{~m}$ (width $\times$ length $\times$ height). These modules were placed in such a way that four tubes were facing east and the other four faced west. The tubes were placed $0.20,0.50,0.80$ and $1.10 \mathrm{~m}$ above soil level (Figure 1).

On the upper part of the tubes (containers) $4 \mathrm{~cm}$ orifices were made every $25 \mathrm{~cm}$ and filled with composted wood bark shredded to $3 \mathrm{~mm}$; its physical properties were $74 \%$ moisture retention, $1.66 \mathrm{~g} \mathrm{~cm}^{-3}$ particle density, $0.46 \mathrm{~g} \mathrm{~cm}^{-3}$ bulk density, $72.40 \%$ total pore space, $14.30 \%$ aeration capacity and $24.20 \%$ easily available water. In each orifice, a strawberry runner (Fragaria ananassa) cv. Camino Real was planted.

\section{Treatments}

The treatments were four container heights $(0.20,0.50,0.80$ and $1.10 \mathrm{~m})$ and two orientations (east and west). Each treatment was replicated three times and the experimental unit was one lot of 12 plants. An experimental design of complete random blocks was used with factorial array.

\section{Fertigation parameters}

Plants were fertigated with nutrient solution ( $\left.\mathrm{mg} \mathrm{L}^{-1}\right)$ : N (250), P (60), K (300), S (200), Mg (75), Fe (3), Mn (0.5), B (0.5), $\mathrm{Cu}(0.1)$ and $\mathrm{Zn}(0.1)$. Volume of daily fertigation depended on the crop development stage, plus an addition between 15 and $25 \%$ to compensate drainage (Urrestarazu, 2004). pH and electric conductivity (EC) were measured weekly and adjusted to 5.5-6.5 and 2.0-2.6 $\mathrm{dS} \mathrm{m}^{-1}$, respectively. Volume of fertigation was measured with a graduated cylinder, and $\mathrm{pH}$ and EC with a potentiometer model $211 \mathrm{R}$ (Hanna Instruments ${ }^{\circledR}$, USA).

Temperature, relative humidity and overall radiation

Temperature $\left({ }^{\circ} \mathrm{C}\right)$ and relative humidity (\%) inside the greenhouse were recorded every five minutes with a Datalogger U23-001 $\left(\mathrm{HOBO}^{\circledR}\right.$ Pro v2 Temp/RH, USA). Global radiation (W $\mathrm{m}^{-1}$ ) was obtained with a S-LIB-M003 sensor $\left(\mathrm{HOBO}^{\circledR}\right.$, USA). Duration of the photoperiod (sunlight in a day) was estimated with data on global radiation above $1.0 \mathrm{~W} \mathrm{~m}^{-2}$ (Christiaens et al., 2014).

\section{Photosynthetically Active and} Integrated Radiation

PAR $\left(\mu \mathrm{mol} \mathrm{m} \mathrm{m}^{-2} \mathrm{~s}^{-1}\right)$ was recorded every hour from $8: 00$ to $16: 00 \mathrm{~h}$, two days a week during the entire crop cycle. PAR was measured outside the greenhouse $1.10 \mathrm{~m}$ above ground level and inside above the canopy of the plants in each container with a portable linear quantum radiation meter MQ301 (Apogee Instruments $^{\circledR}$, Inc. UT. USA). IPAR mol m${ }^{-2}$ day $^{-1}$ was obtained following Chang et al. (2008) at each height and orientation of the crop.

\section{Fruit yield and quality}

Fruits were harvested from January to June 2016. Yield was obtained following norm NMX-FF-062-1987, considering the sum of the weekly fruit harvest during the entire productive stage of the crop. The content of total soluble solids ( ${ }^{\circ} \mathrm{Brix}$ ) was determined in a sub-sample of three fruits per picking, with a digital refractometer (HI 96801, HANNA Instruments ${ }^{\circledR}$ ).

\section{Statistical analysis}

The obtained data were subjected to analysis of variance and the Tukey multiple comparison of means. 
For the variable yield and IPAR, a correlation was performed with a fit to a second order polynomial regression (Montgomery, 2006). For all analyses, the statistical software SAS, version 9.0 (SAS Institute, 2002) was used.

\section{RESULTS AND DISCUSSION}

\section{Analysis of variance}

The analysis of variance shows significant statistical difference in all evaluated variables for the factor height. These differences are due to differences in photosynthetically active radiation the plants received at different heights. For the factor orientation and combination of factors, none of the variables was statistically different. The similarity among variables may be due to the similar PAR the plants received during the day in the two orientations.

\section{Fertigation parameters}

The different container heights were significantly different $(\mathrm{P} \leq 0.01)$ in the variables $\mathrm{pH}, \mathrm{EC}$ and percentage of fertigation drainage (Table 1). The highest values of $\mathrm{pH}$ (7.49 and 7.65) were obtained in the drainage of the containers placed 0.80 and $1.10 \mathrm{~m}$ high; these containers also had the highest

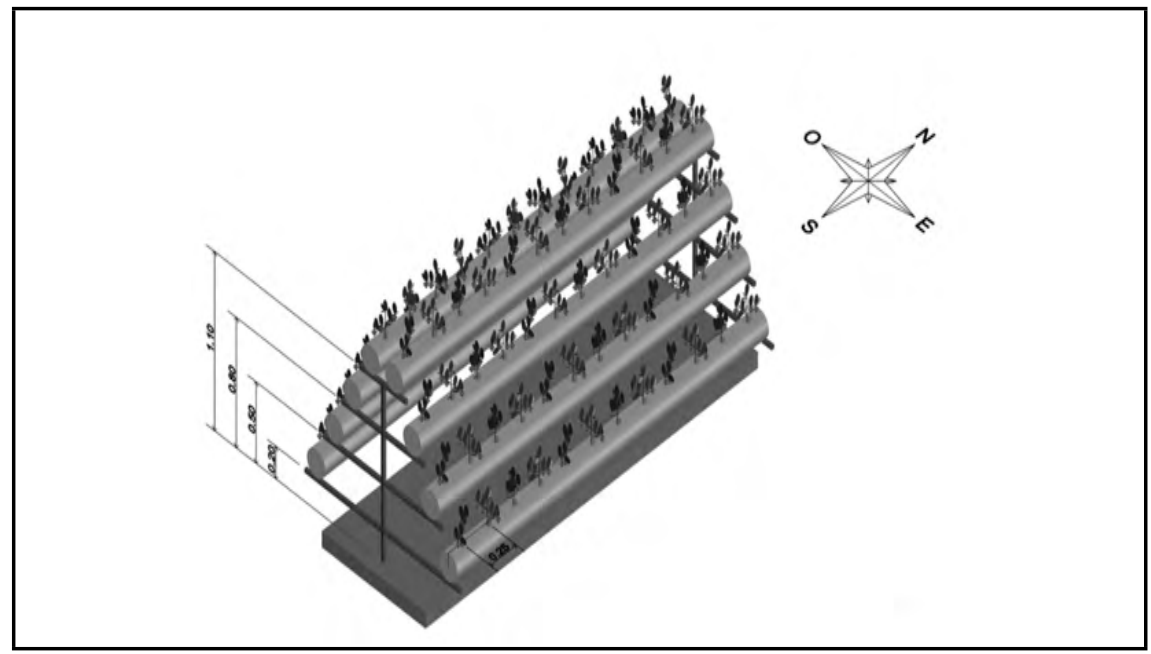

Figure 1. Stair-like hydroponic module for the cultivation of strawberry cv. Camino Real, built with PVC containers in a stepped configuration at $0.20,0.50,0.80$ and $1.10 \mathrm{~m}$ from the ground and with east-west orientation. Oaxaca, CIIDIR-IPN, 2016. values of EC (1.32 and $\left.1.37 \mathrm{dS} \mathrm{m}^{-1}\right)$. Only the $1.10 \mathrm{~m}$ high container had the lowest percentage of drainage $(12.33 \%)$. These differences occurred because the highest container received more PAR and IPAR, which induced higher water uptake, a decrease in drainage and an increase in concentration of salts. Morales \& Urrestarazu (2013) observed similar results in a crop of hydroponic tomatoes.

Temperature, relative humidity
Table 1. Fertigation and drainage parameters in containers at different heights and in the strawberry crop. Oaxaca, CIIDIR-IPN, 2016.

\begin{tabular}{lccc}
\hline Container height $(\mathbf{m})$ & $\mathbf{p H}$ & $\mathbf{E C}\left(\mathbf{d S ~ m}^{-1}\right)$ & Drainage (\%) \\
\hline 0.20 & $6.92 \mathrm{c}^{*}$ & $1.18 \mathrm{~b}$ & $23.50 \mathrm{a}$ \\
0.50 & $7.23 \mathrm{~b}$ & $1.19 \mathrm{ab}$ & $23.67 \mathrm{a}$ \\
0.80 & $7.49 \mathrm{ab}$ & $1.32 \mathrm{ab}$ & $24.67 \mathrm{a}$ \\
1.10 & $7.65 \mathrm{a}$ & $1.37 \mathrm{a}$ & $12.33 \mathrm{~b}$ \\
\hline $\mathrm{CV}(\%)$ & 10.28 & 8.34 & 16.40 \\
\hline
\end{tabular}

*Means with different letters in a column are statistically different (Tukey, $\mathrm{P} \leq 0.05$ ).

\section{and global radiation}

During the crop cycle, average temperatures inside and outside the greenhouse were 27.5 and $18.5^{\circ} \mathrm{C}$, while average relative humidity inside and outside the greenhouse was 45.5 and $69.7 \%$. According to Kadir \& Sidhu (2006), these values of temperature and relative humidity are suitable and favor strawberry development and production. Average monthly global radiation recorded inside the greenhouse from January to June was $11.7,12.9$, 14.0, 15.7, 16.3 and $14.1 \mathrm{MJ} \mathrm{m}^{-2} \mathrm{~d}^{-1}$, respectively, and was within the range required by strawberries (Torres \& Lopez, 2011).

\section{Photosynthetically Active Radiation}

PAR was significantly different $(\mathrm{P} \leq 0.01)$ for the east and west orientation and container heights at 09:00, 12:00 and 16:00 hours (Figure 2a, 2b and 2c, respectively), but between orientations,

Table 2. Total soluble solids in strawberry fruits produced at different heights in stair-like containers. Oaxaca, CIIDIR-IPN, 2016.

\begin{tabular}{lcccccc}
\hline \multirow{2}{*}{$\begin{array}{l}\text { Container height } \\
(\mathbf{m})\end{array}$} & January & February & March & April & May & June \\
\cline { 2 - 7 } & & \multicolumn{5}{c}{ Total soluble solids ( ${ }^{\circ}$ Brix) } \\
\hline 0.20 & $6.57 \mathrm{a}^{*}$ & $7.21 \mathrm{a}$ & $6.38 \mathrm{c}$ & $7.31 \mathrm{~b}$ & $7.81 \mathrm{c}$ & $8.33 \mathrm{~b}$ \\
0.50 & $6.28 \mathrm{a}$ & $7.69 \mathrm{a}$ & $6.88 \mathrm{bc}$ & $7.32 \mathrm{~b}$ & $8.71 \mathrm{bc}$ & $9.26 \mathrm{ab}$ \\
0.80 & $6.92 \mathrm{a}$ & $7.08 \mathrm{a}$ & $7.49 \mathrm{ab}$ & $8.82 \mathrm{a}$ & $9.42 \mathrm{ab}$ & $9.92 \mathrm{ab}$ \\
1.10 & $6.22 \mathrm{a}$ & $7.10 \mathrm{a}$ & $7.84 \mathrm{a}$ & $8.65 \mathrm{a}$ & $10.80 \mathrm{a}$ & $11.45 \mathrm{a}$ \\
\hline CV (\%) & 17.20 & 10.20 & 11.70 & 12.20 & 15.90 & 25.60 \\
\hline
\end{tabular}

*Means with the same letter are not significantly different (Tukey, $\mathrm{P} \leq 0.05$ ). 
average daily PAR received was not different. However, it was different from the PAR outside the greenhouse (Figure 2d), whose maximum was $1300 \mu \mathrm{mol}$ $\mathrm{m}^{-2} \mathrm{~s}^{-1}$, much higher than the $900 \mu \mathrm{mol}$ $\mathrm{m}^{-2} \mathrm{~s}^{-1}$ obtained at midday inside the greenhouse and at the highest containers. This behavior of PAR is due to a higher angle of incidence of the sunrays both in the morning (east orientation) and in the afternoon (west orientation) and the vertical rays at midday. The strawberry plants cultivated in the containers 1.10 $\mathrm{m}$ high received an average of $842 \mu \mathrm{mol}$ $\mathrm{m}^{-2} \mathrm{~s}^{-1}$ during the day, while those that grew $0.20 \mathrm{~m}$ above the ground received $502 \mu \mathrm{mol} \mathrm{m}{ }^{-2} \mathrm{~s}^{-1}$; that is, the higher plants received $67 \%$ more PAR than the lower ones.

Plants growing in containters at all heights captured more PAR than the 400 $\mu \mathrm{mol} \mathrm{m} \mathrm{m}^{-2} \mathrm{~s}^{-1}$ captured by greenhouse strawberries, cultivar Honeoye, reported by Bradford et al.(2010), and more than the $270 \mu \mathrm{mol} \mathrm{m} \mathrm{m}^{-2} \mathrm{~s}^{-1}$ reported by Sonsteby \& Heide (2006) in the cultivars "Korona" and "Elsanta". The PAR obtained in this study at different heights and orientations of the containers was higher than the PAR required by the species, which oscilates between 200 and $400 \mu \mathrm{mol} \mathrm{m}^{-2} \mathrm{~s}^{-1}$ (Torres \& Lopez, 2011). Therefore, with good crop management, which includes timely irrigation, fertilization, and pest and disease control, yields can be higher than that of the traditional system in soil since PAR is not a limiting factor.

Integrated Photosynthetically Active Radiation
The IPAR received by strawberry plants cultivated in stair-like containers was significantly different among heights and different from the exterior IPAR, which reached the maximum value $\left(49 \mathrm{~mol} \mathrm{~m}^{-2} \mathrm{~d}^{-1}\right)$. The highest IPAR was registered on plants in the $1.10 \mathrm{~m}$ high container with $29.8 \mathrm{~mol} \mathrm{~m}^{-2} \mathrm{~d}^{-1}$. This value of IPAR decreased in function of lowering heights of the containers to the lowest value of $19.0 \mathrm{~mol} \mathrm{~m}^{-2} \mathrm{~d}^{-1}$ in plants of the container at $0.20 \mathrm{~m}$ high. All the plant heights had IPAR values above those reported by Bradford et al. (2010), Sonsteby \& Heide (2006), Verheul et al. (2007) and Casierra-Posada et al. (2012) in greenhouse strawberries.

Strawberry plants have a low IPAR requirement $\left(10-20 \mathrm{~mol} \mathrm{~m}^{-2} \mathrm{~d}^{-1}\right)$, unlike other plants such as tomato $(S$.

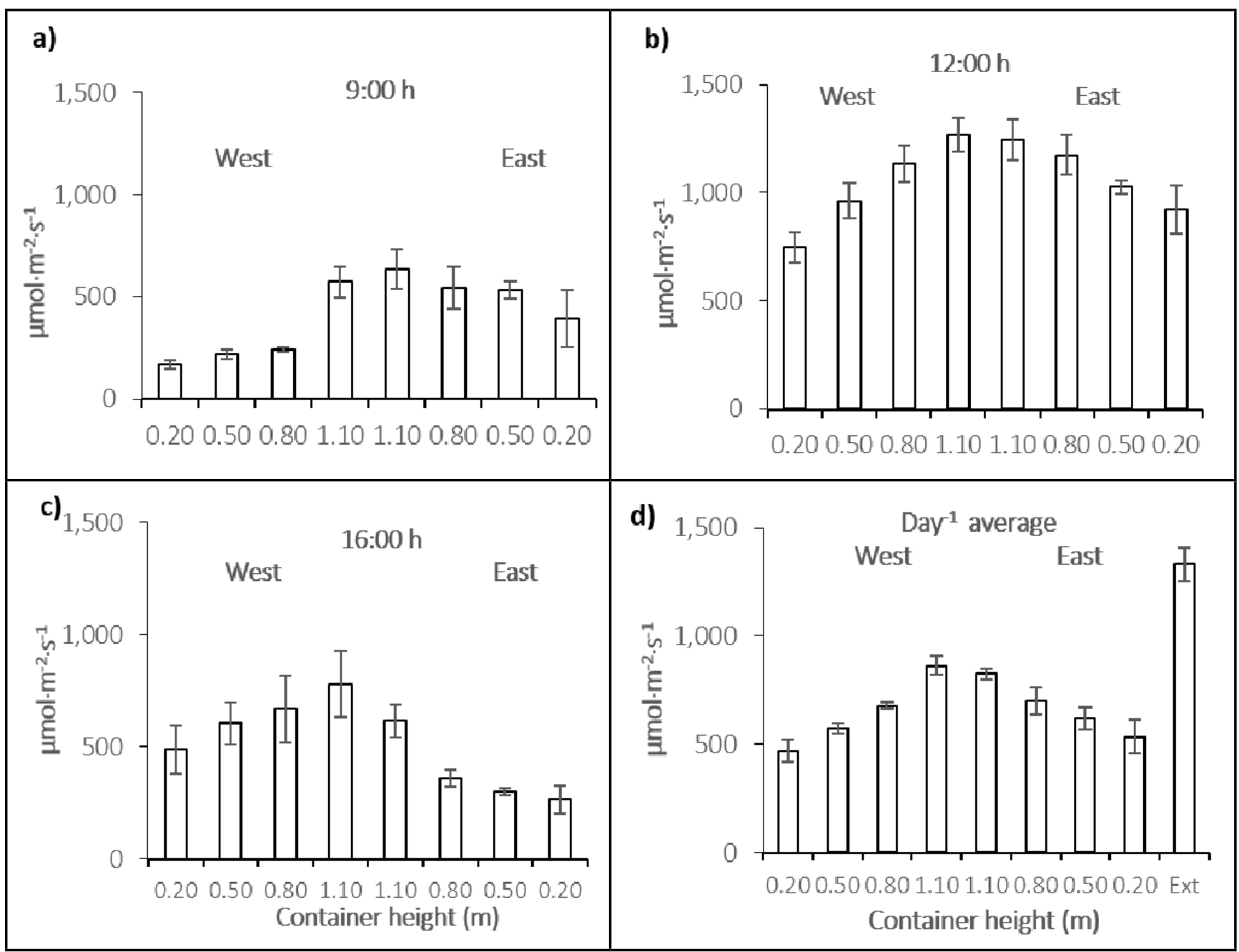

Figure 2. Photosynthetically Active Radiation registered in the canopy of strawberry plants cultivated in containers on stair-type structure with east and west orientation at three times of the day: a) 9:00 h; b) 12:00 h; c) 16:00 h and d) daily average. Ext: PAR recorded outside the greenhouse. Oaxaca, CIIDIR-IPN, 2016. 
lycopersicum), which needs 30-35 mol $\mathrm{m}^{-2} \mathrm{~d}^{-1}$ (Hernández \& Kubota, 2014). Therefore, the IPAR values obtained at different plant heights on the stair-like system satisfy the requirements for this species.

\section{Yield}

Total strawberry crop yield in the stair-like system had significant differences $(\mathrm{P} \leq 0.05)$ among plant heights (Figure 3 ). Yield of plants grown in containers placed $0.50,0.80$ and $1.10 \mathrm{~m}$ high were not significantly different and were on average $47 \%$ higher than yield of plants cultivated in $0.20 \mathrm{~m}$ high containers. The low yield of strawberry plants in the lowest container was associated with a decrease in PAR caused by shading by the upper containers at some point in the day, coinciding with results with tomato (Solanum lycopersicon) reported by Sánchez-del-Castillo et al. (2014), who indicate that in a stair-like system the lower containers receive less radiation and produce fewer floral buds and, thus, yield is lower.

\section{Total Soluble Solids}

In the months of lower temperature and radiation (January and February) there were no significant differences in total soluble solids in fruit among container heights. However, differences were found in the three months of

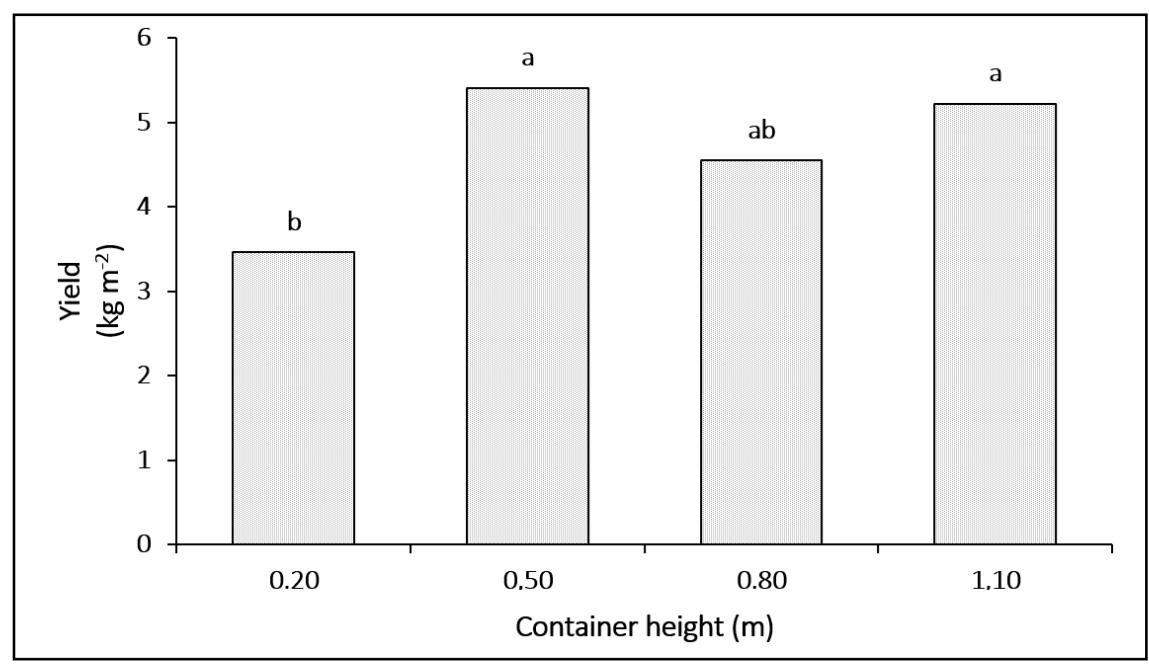

Figure 3. Yield of strawberries produced in containers at different heights in a stair-like system. Means with the same letter are not significantly different (Tukey, $\mathrm{P} \leq 0.05$ ).Oaxaca, CIIDIR-IPN, 2016.

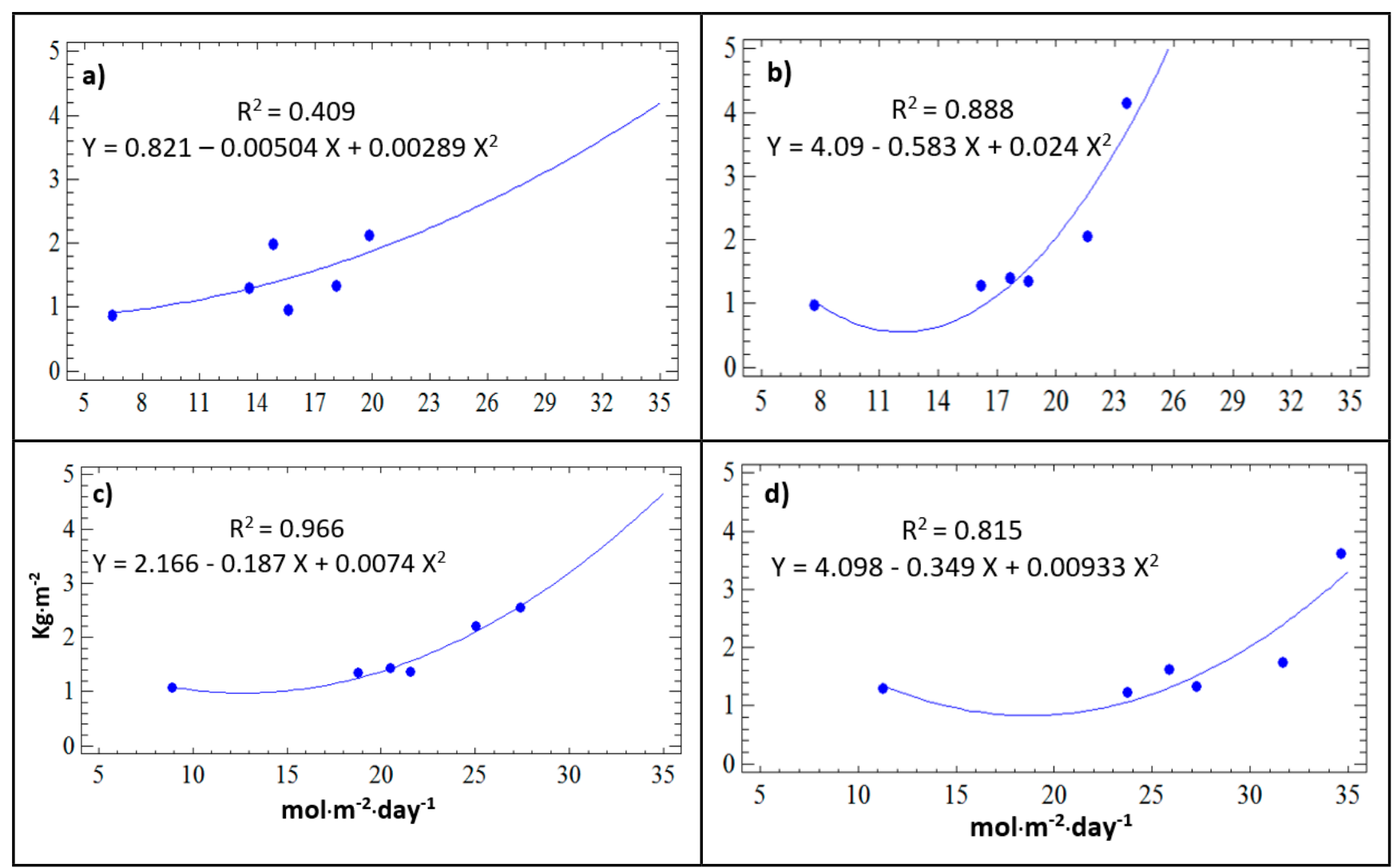

Figure 4. Correlation between IPAR and yield of strawberry produced in stair-like containers at different heights: a) $0.20 \mathrm{~m}, \mathrm{~b}$ ) $0.50 \mathrm{~m}$, c) $0.80 \mathrm{~m}$ and d) $1.10 \mathrm{~m}$. Oaxaca, CIIDIR-IPN, 2016. 
IPAR increases the content of soluble solids in strawberries. Ayub et al. (2016) reported values of total soluble solids in the range of 6.57 and $7.93^{\circ} \mathrm{Brix}$ in the cultivar Camino Real, similar to those obtained in the lowest container during the entire crop cycle, while Cecatto et al. (2013), with the same cultivar, obtained $5.43^{\circ} \mathrm{Brix}$, which is lower than that obtained in fruits produced in the $0.20 \mathrm{~m}$ high container. Casierra-Posada et al. (2011) concluded that diffused and direct radiation directly affect the sugar content in fruits. However, our study shows that the content of total soluble solids in strawberry fruits produced in the stair-like system in a greenhouse did not decrease considerably.

Correlation between Photosynthetically Active Radiation and Yield

Yield of strawberry cultivated in containers $0.50,0.80$ and $1.10 \mathrm{~m}$ high correlated significantly $(\mathrm{P} \leq 0.05)$ with IPAR, with high $\mathrm{R}^{2}: 0.88,0.96$ and 0.81 (Figure 4b, 4c and 4d), respectively. Correlation between yield of plants grown in $0.20 \mathrm{~m}$ high containers and IPAR was low, with an $\mathrm{R}^{2}=0.40$ (Figure 4a). These results are similar to those obtained by Kjaer et al. (2012), who obtained a linear relationship between accumulated dry matter and PAR, indicating that fresh matter increases proportionally with dry matter when PAR increases. The high values of $\mathrm{R}^{2}$ of the three higher containers, relative to that of the lowest container, confirm the positive relationship between PAR and higher yield of strawberries grown in stair-like systems.

It is concluded that the Incidence of PAR and IPAR received by strawberry plants at all heights of the containers in the morning was significantly different from that received in the afternoon in function of geographic orientation. However, the daily average values were similar. Yield was significantly higher in containers at $0.50,0.80$ and $1.10 \mathrm{~m}$ high than in the $0.20 \mathrm{~m}$ high container, $47 \%$ higher. The higher the container, the higher the content of total soluble solids in strawberry fruits during the months of higher temperature and radiation. The strawberry production system of stair-like containers is a viable option for increasing strawberry yield and quality in intensive protected systems.

\section{ACKNOWLEDGEMENTS}

The authors thank the Instituto Politécnico Nacional for funding this project (SIP-20160437).

\section{REFERENCES}

AYUB, R; BOSETO, L; GALVAO, C; ETTO, R; INABA, J; LOPES, P. 2016. Abscisic acid involvement on expression of related gene and phytochemicals during ripening in strawberry fruit Fragaria x ananassa cv. Camino Real. Scientia Horticulturae 203: 178-184.

BRADFORD, E; HANCOCK, J; WARNER, R. 2010. Interactions of temperatures and photoperiod determine expression of repeat flowering in strawberry. Journal of the American Society for Horticultural Science 135: 102-107.

CALVETE, EO; NIENOW, AA; WESP, CL; CESTONARO, L; MARIANI, F; FIOREZE, I; CECCHETTI, D; CASTILHOS, T. 2007. Hydroponic strawberry production in vertical columns system under protected cultivation. Revista Brasileira de Fruticultura 29: 524529.

CASIERRA-POSADA, F; PEÑA-OLMOS, JE; VARGAS-MARTÍNEZ, AF. 2011. Propiedades fisicoquímicas de fresas (Fragaria sp.) cultivadas bajo filtros selectivos. Revista de la Facultad Nacional de Agricultura 64: 6221-6228.

CASIERRA-POSADA, F; PEÑA-OLMOS, JE; ULRICHS, C. 2012. Basic growth analysis in strawberry plants (Fragaria $\mathrm{sp}$.) exposed to different radiation environments. Agronomía Colombiana 30: 25-33.

CECATTO, A; CALVETE, E; NIENOW, A; COSTA R. 2013. Culture systems in the production and quality of strawberry cultivars. Acta Scientiarum Agronomy 35: 471-478.

CHANG, X; ALDERSON, PG; WRIGHT, CJ. 2008. Solar irradiance level alters the growth of basil (Ocimum basilicum L.) and its content of volatile oils. Environmental and Experimental Botany 63: 216-223.

CHRISTIAENS, A; LOOTENS, P; ROLDANRUIZ, E; PAUWELS, E; GOBIN, B; VAN LABAKE, M. 2014. Determining the minimum daily light integral for forcing of azalea (Rhododendron simsii). Scientia Horticulturae 177: 1-9.

ESPAÑA-BOQUERA, M; CHAMPO, J; LOBIT, P; ARELLANO, F; CARDENAS, RF. 2015. Modelo informático para la construcción de doseles virtuales de fresa. Revista Mexicana de Ciencias Agrícolas 6: 291-302.

FERNANDES-JÚNIOR, F; FURLANI, P; RIBEIRO, I. 2002. Produção de frutos e estolhos do morangueiro em diferentes sistemas de cultivo em ambiente protegido.
Bragantia 61: 25-34.

GENT, MPN. 2014. Effect of daily light integral on composition of hydroponic lettuce. HortScience 49: 173-179.

HERNÁNDEZ, R; KUBOTA, C. 2014. Growth and morphological response of cucumber seedlings to supplemental red and blue photon flux ratios under varied solar daily light. Scientia Horticulturae 173: 92-99.

HIGASHIDE, T. 2008. Light interception by tomato plants (Solanum lycopersicum) grown on a sloped field. Agricultural and Forest Meteorology 149: 756-762.

JOHKAN, M; SHOJI, K; GOTO, F; HAHIDA, S; YOSHIHARA, T. 2012. Effect of green light wavelength and intensity on photomorphogenesis and photosynthesis in Lactuca sativa. Environmental and Experimental Botany 75: 128-133.

KADIR, S; SIDHU, G. 2006. Strawberry (Fragaria $x$ ananassa Duch.) Growth and productivity as affected by temperature. HortScience 41: 1423-1430.

KJAER, KH; OTTOSEN, CO; JØRGENSEN, BN. 2012. Timing growth and development of Campanula by daily light integral and supplemental light level in a cost-efficient light control system. Scientia Horticulturae 143: 189-196.

LÓPEZ-LOZANO, R; BARET, F; CHELLE, M; RODCHDI, N; ESPAÑA, M. 2007. Sensitivity of gap fraction to maize architectural characteristics based on 4D model simulations. Agriculture and Forest Meteorology 143: 217-229.

LÓPEZ, RG; RUNKLE, ES. 2008. Photosynthetic daily light integral during propagation influences rooting and growth of cuttings and subsequent development of New Guinea impatiens and petunia. HortScience 43: 2052-2059.

MONTGOMERY, DC. 2006. Diseño y análisis de experimentos. $2^{\mathrm{a}}$ ed. México: Wiley. 700p.

MORALES, I; URRESTARAZU, M. 2013. Thermography study of moderate electrical conductivity and nutrient solution distribution system effects on grafted tomato soilless culture. HortScience 48: 1508-1512.

NORMAN, JM; ARKEBAUER, TJ. 1991. Predicting canopy photosynthesis and light use efficiency from leaf characteristics. In: BOOTE, KJ; LOOMIS RS (eds). Modeling crop photosynthesis from biochemistry to canopy. Crop Science Society of America p.75-94.

OYARZÚN, R; STÖCKLE, C; WU, J; WHITING, M. 2011. In field assessment on the relationship between photosynthetic active radiation (PAR) and global solar radiation transmittance through discontinuous canopies. Chilean Journal of Agricultural Research 71: 122-131.

PRNF - Plan Rector Nacional, Sistema Producto Fresa. 2012. Available at: $<$ http://dev. pue.itesm.mx/sagarpa/nacionales/EXP CNSP FRESA/PLAN\%20RECTOR $\% 20$ QUE\%20CONTIENE\%20PROGRAMA\%20 DE\%20TRABAJO\%202012/PR CNSP FRESA_2012.pdf $>$. Accessed April 26, $201 \overline{7}$.

SAGARPA. 2016. Secretaría de Agricultura, Ganadería, Desarrollo Rural, Pesca y 
Alimentación. Available at: <http://www. sagarpa.gob.mx/Delegaciones/distritofederal/ boletines/Paginas/JAC_00134_14.aspx.> Accessed May 24, 2017.

SÁNCHEZ-DEL-CASTILLO, F; MORENOPÉREZ, EC; CRUZ-ARELLANES, EL. 2009. Producción de jitomate hidropónico bajo invernadero en un sistema de dosel en forma de escalera. Revista Chapingo Serie Horticultura 15: 67-73.

SÁNCHEZ-DEL-CASTILLO, F; MORENOPEREZ, E; CRUZ-ARELLANES, E. 2014 Rendimiento de jitomate con diferentes métodos de cultivo hidropónico basados en doseles escaleriformes. Revista Chapingo Serie Horticultura 20: 239-251.

SAS. 2002. SAS/STAT. User's guide, software version 9.0. Cary, N.C. EEUU: SAS Institute Inc. $4424 \mathrm{p}$.

SIAP. 2018. Sistema de Información Agroalimentaria y Pesquera. México. Available at: <www.siap.gob.mx.>. Accessed on November 14, 2019.

SONSTEBY, A; HEIDE, OM. 2006. Dormancy relations and flowering of the strawberry cultivars Korona and Elsanta as influenced by photoperiod and temperature. Scientia
Horticulturae 110: 57-67.

TORRES, AP; LOPEZ, RG. 2011. Photosynthetic daily light integral during propagation of Tecoma stans influences seedling rooting and growth. HortScience 46: 282-286.

URRESTARAZU, M. 2004. Tratado de cultivo sin suelo. Madrid: Mundi-Prensa. 916p.

VERHEUL, MJ; SØNSTEBY, A; GRIMSTAD, SO. 2007. Influences of day and night temperatures on flowering of Fragaria $x$ ananassa Duch., cvs. Korona and Elsanta, at different photoperiods. Scientia Horticulturae 112: 200-206. 